\title{
LETTERS
}

\section{HIV and contraception}

Thank you for publishing the article on HIV and contraception ${ }^{1}$ in the January issue of the Journal. The advice was succinct and helpful. I would just like to add one point. Namely, that all effective methods of contraception will reduce the spread of HIV in a population. This is achieved by reducing the opportunity for mother-to-child transmission during pregnancy.

Karen Trewinnard, BM, MFFP

Ship's Doctor, MV Doulos, Alte Neckarelzer Strasse2, 74821 Mosbach, Germany. E-mail: Karen.Trewinnard@MVDOULOS.ORG

1 Waters L, Barton S. Contraception and HIV: what do we know and what needs to be done? J Fam Plann Reprod
Health Care 2006; 32: 10-14.

\section{HIV and contraception}

I read with great interest the review by Drs Waters and Barton on contraception and HIV.1

The position is clear in HIV-discordant couples (i.e. where one partner is HIV negative) and the authors have rightly concluded that a barrier contraceptive should be combined with another method of contraception when advising these couples. The risk of horizontal transmission with each unprotected act of intercourse is difficult to quantify as it is dependent on a number of factors including stage of HIV infection, response to antiretroviral treatment, and presence of local infection. ${ }^{2}$ Moreover, the risk of HIV transmission is significantly increased if either or both the HIV-infected and uninfected partner has another sexually transmitted infection ${ }^{3}$

As regards HIV concordant couples, there is a possibility of transmission of resistant virus. Therefore these couples should also be strongly encouraged to avoid unprotected intercourse and use a reliable barrier method of contraception in addition to another method of contraception. ${ }^{2}$

I would be grateful for the author's thoughts on this matter.

Shaur K Qureshi, MRCOG, DFFP

Senior House Officer, Department of Obstetrics and Gynaecology, Nobles Hospital, Strang Braddan, Isle of Man IM4 4RJ, UK

References

Waters L, Barton S. Contraception and HIV: what do we know and what needs to be done? J Fam Plann Reprod

Obstetriciand Madge S, Johnson MA. HIV and pregnancy. The

to public health policy and practice: the conical synergy HIV infection. Sex Transm Infect 1999; 75: 3-17.

Reply

We would like to thank the respondents to our recent article ${ }^{1}$ for their comments.

With regard to Qureshi's comments on transmission of resistance virus between seroconcordant couples, we agree that the use of barrier contraception in addition to other methods should be advised. Although, in practice, super-infection with new viral strains is uncommon, independent viral replication in the genital tract means one cannot rely on plasma viral load as a marker of risk for unprotected sexual intercourse. Additional factors such as the presence of concurrent sexually transmitted infections may increase viral shedding and transmission risk.

With regard to Robinson's comments on the association between hormonal contraception and cervical shedding of virus, the evidence is contradictory; we would normally counsel the additional use of barrier contraceptives anyway.

Finally, we agree with Trewinnard that the judicious use of effective contraception will indeed reduce HIV transmission by the motherto-child transmission route.
Laura J Waters, MRCP

Specialist Registrar in Genitourinary Medicine, St Stephen's Centre, Chelsea \& Westminster Hospital, 369 Fulham Road, London SW10 9NH, UK.E-mail: laura.waters@chelwest.nhs.uk

Simon E Barton, FRCOG, FRCP

Clinical Director, St Stephen's Centre, Chelsea \& Westminster Hospital, 369 Fulham Road, London SW10 9NH, UK

\section{Reference \\ Waters L, Barton S. Contraception and HIV: what do we know and what needs to be done? J Fam Plann Reprod}

\section{Nurse prescribing}

As a group of extended nurse prescribers working in the field of contraception and sexual health we are writing to express our concerns about the limitations of not being able to prescribe medicines outside the terms of the product licence.

We are aware that nurse prescribers should not currently prescribe medicines independently for uses outside their licensed indications, and that this decision has been subject to consultation and that the Medicines and Healthcare products Regulatory Agency (MHRA) will be considering responses before putting them to the Committee on Safety of Medicines in the autumn. However, we feel that much prescribing in the field of contraception is off licence, so much so that the FFPRHC Guidance paper on this topic ${ }^{1}$ (July 2005) covers 17 pages!

Many summary product characteristics (SPC) sheets are so out of date that the patient information leaflets provide women with information which conflicts with alternative evidence-based sources of patient information such as the fpa (Family planning Association) leaflets. Examples of the impact this has on our practice include the following. We cannot advise a woman to start her pill later than Day 1. We cannot not apply the criteria for being 'reasonably certain' a woman is not pregnant so as to allow $>5$ days start of the combined oral contraceptive (COC). We cannot advise tri-cycling to prevent withdrawal bleed, reduce menstrual bleeding problems, premenstrual symptoms, or to avoid withdrawal headaches.

We cannot recommend a shortened pill-free interval for women with a true pill failure, or for those on liver enzyme-inducers. Likewise we cannot prescribe two low-dose COCs to give $50 \mu \mathrm{g}$ for women on liver enzyme-inducers. We cannot increase the doses of emergency hormonal contraception (EHC) for women on liver enzyme-inducers. We cannot offer progestogenonly emergency contraception beyond 72 hours. We cannot offer EHC more than once per cycle. We cannot 'quick start' COC following EHC. We cannot offer a short course of COC/progestogenonly pill for women experiencing initial bleeding problems with an implant.

There are many other situations where best practice would allow our medical colleagues to prescribe out of licence. The above examples of out-of-licence prescribing do not constitute any increased risk to the patient and would all be implemented following careful and detailed assessment and would be in the women's best interest.

Nurse prescribers, working in the area of contraception, want to provide women, of all ages, with optimum care, which is being compromised by outdated SPCs. We hope that the MHRA will apply commonsense and reason to their decisions relating to this important area of health care

\section{Sue Williams, RGN}

Clinical Nurse Specialist, Contraception and Sexual Health Service, Easington PCT, Centre for Health, Whitehouse Business Park, Peterlee SR82RT, UK, E-mail: Sue.williams@ easingtonpct.nhs.uk

\section{Gill Tyro, RGV, BSc}

Nurse Co-ordinator, Contraception and Sexual Health, James Reed House, Beeston Village Medical Centre, Town Street, Leeds LS11 8PN, UK.E-mail:gtyro@nhs.net

Sue Wouters, RGN, RHV

Nurse Prescriber, Contraception and Sexual Health, James Reed House, Beeston Village Medical Centre, Town Street, Leeds LS11 8PN, UK.E-mail:sue.wouters@ ntlworld.com

Ayesha Boadle-Soumah, RGN, MPH

Advanced Practitioner, Contraception and Sexual Health, James Reed House, Beeston Village Medical Centre, Town Street, Leeds LS11 8PN,UK E-mail: ayesha.boadle-soumah@ nhs.net

Reference

Faculty of Family Planning and Reproductive Health Care Clineal Electiveness Unit. FFPRHC Guidance (July 2005). The use of contraception outside the terms of the product $225-242$

\section{Nurse prescribing}

I was disappointed and somewhat dismayed to read the article on 'Nurse prescribing in family planning' in the January 2006 issue of the Journal. ${ }^{1}$

As an extended independent nurse prescriber since 2002, I believe the implementation of the extended formulary has been the single most important factor in promoting the appropriate use of skilled and experienced nurses within the specialty

Ms Young bemoans the fact that a challenging course of education and assessment is required before nurses can take on this role, and believes that by dint of being a nurse this equates to competence in prescribing. Admittedly, prior to nurse prescribing and the advent of patient group directions (PGDs), many family planning nurses did have the knowledge and skills to assess and treat their patients. However, legitimising this activity has recognised this, and given these experienced nurses the opportunity to use those skills, enhance their practice and, importantly, accept responsibility for their decisions and actions. We no longer require the rubber stamp of the doctors' signatures to endorse our actions (and how many times in the past were nurses frustrated by doctors' refusal to take our advice). Ms Young appears to be advocating a return to the bad old days, when nurses were dependent on the good will of their medical colleagues to 'allow' them to unofficially prescribe, and to carry the can if wrong decisions were made.

Ms Young's frustration at the pharmacist's refusal to comply with her request for her friend is perhaps understandable. However, I suspect most pharmacists would be reluctant to accept a direction from an unknown person over the telephone; although in my experience, most will in fact sell a single packet of contraceptive pills to patients in an emergency. Perhaps, in this case, in view of her friend's 'blinding headaches' this decision was not so wrong.

Family planning has been shown to be one of the most common areas in which nurses prescribe. Already, nurses are able to prescribe the complete range of contraceptives, and the expansion of nurse prescribing this year will allow qualified prescribers to prescribe independently from the whole formulary, for any condition, as long as it is within their scope of competency. Surely this should be seen as a long-awaited advancement for nurses, not in a purely negative and shortsighted way as a cost-cutting measure.

I do applaud Ms Young's beliefs that all specialist nurses need to have the ability to prescribe in their roles, and agree that this is an aspect that could perhaps be addressed in the education of family planning nurses in the future. However, at present, this is not the case. 